Research Article

\title{
Pavement Manager at Risk in Construction of Hot Mix Asphalt
}

\author{
Hesham Ali and Mohamadtaqi Baqersad \\ Civil and Environmental Engineering, Florida International University, 10555 W. Flagler Street, EC 3680, Miami, FL 33174, USA
}

Correspondence should be addressed to Mohamadtaqi Baqersad; mbaqe001@fiu.edu

Received 10 October 2017; Revised 20 March 2018; Accepted 1 April 2018; Published 25 June 2018

Academic Editor: Cumaraswamy Vipulanandan

Copyright (c) 2018 Hesham Ali and Mohamadtaqi Baqersad. This is an open access article distributed under the Creative Commons Attribution License, which permits unrestricted use, distribution, and reproduction in any medium, provided the original work is properly cited.

\begin{abstract}
Pavement management is part science, part management, and part experience. After several decades of promoting pavement management, many road owners are still reluctant to use it as they lack the knowledge, the experience, or the confidence. The problem is further complicated by the emergence of a large list of new products and techniques that are self-proclaimed to achieve miracles but fall short. The outcome of this arrangement is that thousands of miles of roads still cost more to maintain than if effective pavement preservation techniques were used. This paper attempts to resolve this dilemma by introducing the role of Pavement Manager at Risk (PMAR), allowing a Pavement Manager to offer a long-term pavement preservation service to a client in return for a fixed per-mile premium. This allows the knowledgeable Pavement Manager, who would typically be a Pavement Engineer or a practitioner with extensive knowledge and experience, to implement effective pavement preservation techniques and share the economic benefit with the owner. In this study, the responsibilities of the Pavement Manager at Risk (PMAR) will be introduced. The type of analysis it needs to run will be demonstrated in a case study. In this paper, a sample analysis is presented to present the financial aspects of managing a network of local roads. Pavement treatment cost, pavement condition, and treatment life extension in addition to the admin, mobilization, striping, and occasional patches expenses are presented. The benefits and risks of this approach are described.
\end{abstract}

\section{Introduction}

Pavement management is the process of maintenance and rehabilitation planning of roadways to optimize the pavement condition during its service life. Due to continuous rise of material cost, managers are seeking cost-effective ways to manage the roadways. This paper does not offer a new research on pavement management, but it offers a different arrangement of the role of the pavement manager. The pavement manager, being the most knowledgeable of pavement management techniques and products, is the best suited to reap the financial rewards (or risk) of pavement performance. This arrangement will encourage innovation and support cost-effective products.

There is a variety of asphalt pavement treatment methods used to maintain and preserve the network of paved roads [1]. The main purpose of the pavement treatment is to prevent the pavement from deteriorating to a point where costly rehabilitation becomes necessary [2]. Pavement preservation also has been used to improve wear resistance, build sufficient surface, prevent separation of asphalt aggregate from the asphalt surface, and make the pavement impervious to water influx [3-7].

Maintenance treatments can be effective in treating certain issues in a given condition. The selection of an effective pavement preservation strategy (or group of strategies) depends on many factors, such as pavement condition, pavement type, traffic volume, road class, ambient conditions, specialty contractor availability, and cost, so on. To select the best treatment method, good knowledge of the existing pavement condition, treatment cost, and the life extension due to the pavement treatment is needed [8].

The first step in selecting the best maintenance treatment is evaluating the existing pavement deterioration and condition. There are different ways to define the condition of the pavement. The pavement evaluation method should consider the magnitude of cracks and damage precisely [9]. 
Pavement maintenance has two features, life extension and treatment life [10]. The treatment life is the amount of time that treatment can enhance the lifespan of an existing pavement to get to a terminal condition. Life extension is the amount of time that treatment can attain to the existing pavement condition after using treatment (Figure 1).

As shown in Figure 1, when the new pavement is constructed, the pavement is in a very good condition. During the service life, the condition is degraded due to the environment and wheel load effect on the pavement $[11,12]$. The maintenance treatment is applied to the pavement surface to improve pavement condition and prevent further degradation of pavement condition. The treatment life is heavily reliant on the number and type of traffic, treatment timing, and climate [13]. Treatments placed on a pavement in good condition or subject to a lower level of traffic will last longer than treatments placed at a high level of traffic or poor pavement condition.

Maintenance treatment cost is another factor that must be considered. There are several methods to perform treatment cost analysis according to the life extension of treatment, treatment cost, and existing pavement condition [14]. The Equivalent United Annual Cost (EUAC) is a popular cost analysis approach that can consider the existing pavement condition, extension of life of the treatment, and treatment cost. This method is selected to be implemented in this study to perform comparative cost analysis because it is practical and simple. In this cost analysis, the treatment material and the paving cost will be considered [15]. However, to perform a complete cost analysis, the long-term cost of treatment should be considered. It is critical that the PMAR performs a detailed cost analysis prior to presenting the owner with the cost of service. In this cost analysis method, the administrative cost, routine and occasional patching cost during the service life of treatment, mobilization, and striping cost also must be considered. The cost of maintenance treatments in Florida as a case study is investigated to select the best treatment method for implementing the concept in Florida.

\section{Pavement Manager at Risk (PMAR)}

Pavement Manager at Risk (PMAR) is a contractual arrangement advocated in this study to promote a wider implementation of effective pavement management. The concept is not new and is implemented in construction management. It is similar to Construction Manager at Risk (CMAR) and design/build arrangements combined. The PMAR needs to be knowledgeable of pavement preservation best practices. It has the following roles and responsibilities:

(1) Studies the pavement network in question

(2) Classifies the roads based on function, class, pavement type, and condition

(3) Determines the most cost-effective solutions

(a) For high-volume versus low-volume roads

(b) For pavements in good condition versus poor condition

(4) Develops a pavement management plan

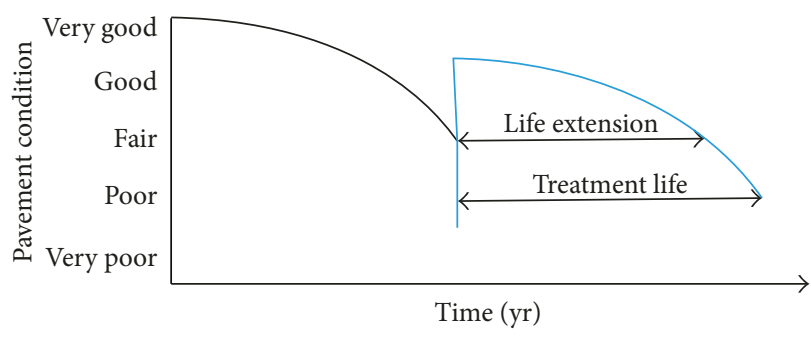

Figure 1: Treatment life and life extension.

(5) Projects routine maintenance (patching and striping) and administrative expenses

(6) Annualizes the cost

(7) Factors for inflation and interest rate

(8) Provides the owner a price per SY*year for the entire network

(9) Warranties a specific level of performance. The proposal to the owner will not include material and labor unit prices, but guarantees performance

(10) Carries out the construction/rehabilitation/ preservation program during the contract term

In order for the PMAR to be successful, it needs to have a good understanding of the pavement treatments and rehabilitation techniques it intends to use.

2.1. The Existing Pavement Condition. Each maintenance treatment of asphalt pavement has special properties that make it different in improving the pavement performance. The existing pavement condition and distresses, at first, should be evaluated to help select the best treatment [16]. The prevailing distress(s) may dictate the type of treatment.

2.2. Treatment Cost and Life Extension. The cost of paving, treatment, admin expenses, and occasional patches are needed during the service life of pavement. Furthermore, the mobilization and striping expenses need to be estimated. The life extension that the treatment will provide for the existing pavement based on the pavement distress is needed to perform the cost analysis using PMAR. A probabilistic approach can be used to characterize the variability. Monte Carlo simulation can be used to simulate variability in cost and predict the variability in pricing to reduce the risk of financial loss. Alternatively, conservative numbers (low projections or life expectancy) can be used to reduce the probability of economic loss on the part of the PMAR.

Figure 2 shows a typical cost analysis conducted by the PMAR. The Equivalent United Annual Cost (EUAC) analysis is used to determine the unit cost of candidate treatments in the units of \$/SY/year. Reliable information on treatment life extension, treatment cost in the local area, traffic level, and pavement condition is needed to determine the EUAC of each candidate treatment.

The annual admin expenses are computed using the usual business expenses, mobilization and striping expenses, and occasional patches expenses in the contract lifespan. 


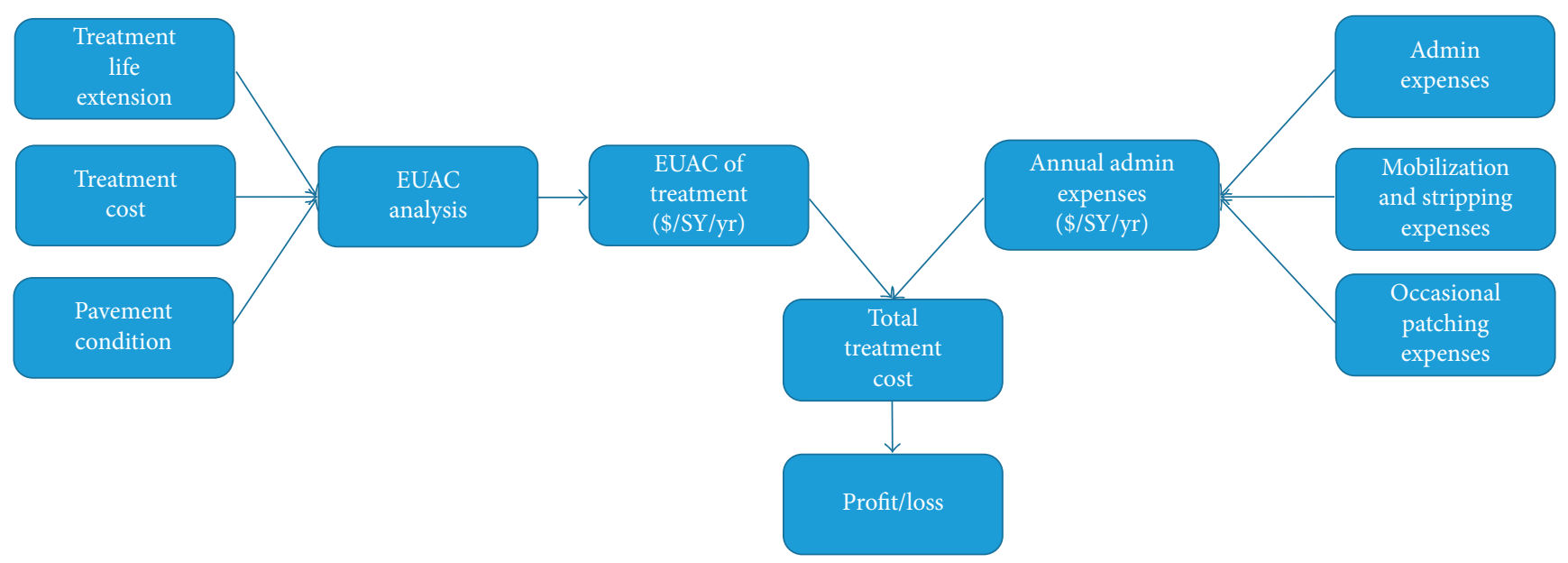

FIgURE 2: PMAR cost analysis.

This cost is then converted to units of $\$ / S Y / y e a r$. In the next step, the PMAR determines the total annual treatment cost by summing up the annual admin expenses and EUAC. Finally, the profit/loss amount is computed by subtracting the total annual cost of work from the projected revenues. Applying and using of the PMAR arrangement to select the best treatment for the existing pavement is described in the following case study.

2.3. Challenges. There are some challenges to the deployment of this arrangement. These include the following:

(1) Cash Flow. If some roads require heavy rehabilitation early on, the PMAR may be required to front money for such rehabilitation. Eventually, the investment will be returned, but the PMAR needs to account for the cost of borrowing money.

(2) Long-Term. This arrangement requires a long-term commitment from the PMAR and the client. The PMAR's actions will impact the network condition for years to come. On the positive side, this forces the PMAR to be thinking long-term and to be foresighted.

(3) Hand over Transition. At the end of the term, the PMAR is expected to return the road network in a condition, as agreed on in the contract. This must be determined upfront and may have an impact on the pricing.

(4) Warranty. The PMAR needs to use pavement condition surveys to determine the current pavement condition and forecast future condition. His contract with the client is performance-based. Performance should be clearly specified and understood by both parties prior to getting in the agreement.

(5) Bonding. The PMAR may need to secure bonding to assure clients of its financial capability. Bonding may add an expense to the example shown here. Further, most bonding in the market is short term, maximum of 5 years. Bonding industry will hopefully evolve to cater to this new line of business.

\section{Case Study}

During this case study, the analysis used by PMAR is described. The data needed to perform the analysis was collected in a literature review and a survey of Florida agencies to derive the average expenses in performing candidate treatments $[17,18]$.

3.1. Existing Pavement Condition. The existing pavement condition should be evaluated to determine the maintenance treatment life and life extension of treatment. The commonly used system in cities and countries for this aim is Pavement Condition Index (PCI). The PCI considers all the aspects of pavement condition and may not be illustrative enough to address the exact condition and problem of pavement regarding its serviceability.

Evaluating the pavement distress in selecting the pavement treatment is important $[13,19]$. If the pavement distress and response (such as deflection) are more than allowable limits, the pavement maintenance will not improve significantly by applying a surface treatment. The pavement will need rehabilitation. Hence, there is a threshold that determines the amount of deterioration in the existing pavement to apply surface treatment.

It was suggested that maximum of $5 \%$ cracking and a minimum Pavement Condition Index (PCI) of 70 be considered for pavement preservation [13]. In this paper, pavement condition is categorized into three conditions. If the cracks are less than 5 percent, the pavement is considered to be in good condition. In fair condition, if the cracks are between 5 percent and 20 percent. In poor condition, if the cracks are more than 20 percent. In poor condition, distress and crack are significant and surface treatments should not be applied.

However, cracks and distresses have a significant effect on the magnitude of life extension of pavements. Since cracks can allow an influx of water into the pavement, the extent of pavement cracks is a significant indication of pavement condition and can change the life extension of applied treatments [20]. 
TABle 1: Pavement life extension (years).

\begin{tabular}{|c|c|c|c|c|c|c|}
\hline \multirow[b]{2}{*}{ Maintenance treatment } & \multicolumn{3}{|c|}{ Pavement life extension for $\mathrm{TI}>6$} & \multicolumn{3}{|c|}{ Treatment life for $\mathrm{TI}<6$} \\
\hline & $\begin{array}{c}\text { Good } \\
\text { Cracks }<5 \%\end{array}$ & $\begin{array}{c}\text { Fair } \\
5 \% \\
<\text { cracks }<20 \%\end{array}$ & $\begin{array}{c}\text { Poor } \\
\text { Cracks }>20 \%\end{array}$ & $\begin{array}{c}\text { Good } \\
\text { Cracks }<5 \%\end{array}$ & $\begin{array}{c}\text { Fair } \\
5 \% \\
<\text { cracks }<20 \%\end{array}$ & $\begin{array}{c}\text { Poor } \\
\text { Cracks }>20 \%\end{array}$ \\
\hline HMA crack sealing & 2.4 & 1 & $\mathrm{~N}$ & 7 & 5 & $\mathrm{~N}$ \\
\hline Fog seals & 0.1 & $\mathrm{~N}$ & $\mathrm{~N}$ & 2 & $\mathrm{~N}$ & $\mathrm{~N}$ \\
\hline Slurry seals & 2.3 & 0.7 & $\mathrm{~N}$ & 9 & 5 & 3 \\
\hline Microsurfacing & 1.8 & 0.5 & $\mathrm{~N}$ & 10 & 6.5 & 3 \\
\hline $\begin{array}{l}\text { PME (polymer-modified emulsion) chip } \\
\text { seals }\end{array}$ & 1.8 & 0.5 & $\mathrm{~N}$ & 10 & 6.5 & 3 \\
\hline $\begin{array}{l}\text { PMA (polymer-modified asphalt) chip } \\
\text { seals }\end{array}$ & 1.8 & 0.5 & $\mathrm{~N}$ & 10 & 7.5 & 5 \\
\hline AR (asphalt rubber) chip seals & 3.8 & 2.8 & 0.7 & 10 & 7.5 & 5 \\
\hline
\end{tabular}

TABLe 2: Pavement treatment EUAC.

\begin{tabular}{lcccc}
\hline Maintenance treatment & $\begin{array}{c}\text { Treatment cost } \$ / \mathrm{SY}^{1}, \\
2015, \mathrm{FL}\end{array}$ & $\begin{array}{c}\text { EUAC }\left(\$ / \mathrm{SY} \mathrm{H}^{1} / \mathrm{yr}\right) \\
\text { Cracks }<5 \%\end{array}$ & $\begin{array}{c}\text { Fair } \\
5 \%<\text { cracks }<20 \%\end{array}$ & $\begin{array}{c}\text { Poor } \\
\text { Cracks }>20 \%\end{array}$ \\
\hline HMA crack sealing & 0.5 & 0.22 & 0.52 & $\mathrm{~N}$ \\
Fog seals & 0.65 & 6.64 & 3.69 & $\mathrm{~N}$ \\
Slurry seals & 2.5 & 1.16 & 8.45 & $\mathrm{~N}$ \\
Microsurfacing & 4.1 & 2.41 & 4.74 & $\mathrm{~N}$ \\
PME chip seals & 2.3 & 1.35 & 4.74 & $\mathrm{~N}$ \\
PMA chip seals & 2.3 & 1.35 & 0.88 & 3.40 \\
AR chip seals & 2.3 & 0.66 & & \\
\hline
\end{tabular}

${ }^{1}$ Square yard.

The treatment life and life extension of different maintenance treatments in Florida are presented in Table 1. The table is arranged by considering different factors that impact the life extension and treatment life. The table is based on Traffic Index (TI) but can be easily converted to Equivalent Single Axle Loads (ESALs) [21]. It can be derived from Table 1 that the most effective maintenance treatment is chip seal, especially for existing pavements with the poor condition because it has the maximum pavement life extension between different maintenance treatments. The pavement treatment methods are described in Table 1.

Fog seal. Fog seal is a light application of a diluted slow-setting asphalt emulsion to the surface of an aged (oxidized) pavement. Fog seals are low-cost and are used to restore flexibility to an existing hot mix asphalt pavement surface [22].

Slurry seal. Slurry seal is a homogenous mixture of emulsified asphalt, water, fine aggregate, and mineral filler that has a creamy fluid-like appearance when applied. Slurry seals are used to fill existing pavement surface defects as either a preparatory treatment for other maintenance treatments or as a wearing course [23].

Microsurfacing. Microsurfacing is a polymer-modified, asphalt emulsion-based, dense-grade, cold-mix, quick-setting, asphalt-resurfacing material. It is designed to be applied in a semi-liquid condition with a specialized mixing and paving machine [24].
TABLE 3: EUAC per SY and admin expenses for chip seals and slurry seals.

\begin{tabular}{|c|c|c|}
\hline Good & Fair & Chip seal \\
\hline$\$ 1.35$ & $\$ 4.74$ & $\begin{array}{c}\text { Chip seal every } 1.8 \text { and } 0.5 \text { for good } \\
\text { and fair }\end{array}$ \\
\hline$\$ 0.08$ & $\$ 0.13$ & Mobilization and striping \\
\hline$\$ 0.08$ & $\$ 0.11$ & Occasional patching \\
\hline$\$ 1.51$ & $\$ 4.98$ & Total contracted expenses for chip seal \\
\hline Good & Fair & Slurry seal \\
\hline$\$ 1.16$ & $\$ 3.69$ & $\begin{array}{l}\text { Slurry seal every } 2.3 \text { and } 0.7 \text { years for } \\
\text { good and fair }\end{array}$ \\
\hline$\$ 0.08$ & $\$ 0.13$ & Mobilization and striping \\
\hline$\$ 0.08$ & $\$ 0.11$ & Occasional patching \\
\hline$\$ 1.32$ & $\$ 3.93$ & Total contracted expenses for slurry seal \\
\hline
\end{tabular}

Chip seals. This treatment is used to waterproof the surface, seal small cracks, and improve friction. It consists of a spray of emulsion followed by a layer of aggregates. There could be a single application or double applications. Although it is used on low-volume roads and streets, it can be used on high-volume highways and expressways [25].

The pavement life extension due to maintenance treatment is related to the location and time of treatment, the climate, facilities, and so on. The average life extension due to each treatment presented in this paper is based on reviewing the literature and agency survey.

3.2. Equivalent United Annual Cost (EUAC). The EUAC is the cost of operating or maintenance of a service during its 
TABle 4: Annual admin expenses per SY.

\begin{tabular}{|c|c|c|c|c|c|c|}
\hline \multicolumn{7}{|c|}{ Assuming $700 \mathrm{~K}$ SF pavement for each client } \\
\hline \multicolumn{4}{|c|}{ Quantity of pavement to be maintained } & \multicolumn{2}{|c|}{ Condition distribution } & \multirow{2}{*}{ Admin expenses $(\$ / S Y / y r$} \\
\hline $\begin{array}{l}\text { Number } \\
\text { of clients }\end{array}$ & SF & SY & Ln-mile & $70 \%$ good & $30 \%$ fair & \\
\hline 1 & 700,000 & 77,778 & 11 & 54,444 & 15,556 & $\$ 1.68$ \\
\hline 2 & $1,400,000$ & 155,556 & 22 & 108,889 & 31,111 & $\$ 0.84$ \\
\hline 3 & $2,100,000$ & 233,333 & 33 & 163,333 & 46,667 & $\$ 0.56$ \\
\hline 4 & $2,800,000$ & 311,111 & 44 & 217,778 & 62,222 & $\$ 0.42$ \\
\hline 5 & $3,500,000$ & 388,889 & 55 & 272,222 & 77,778 & $\$ 0.34$ \\
\hline 6 & $4,200,000$ & 466,667 & 66 & 326,667 & 93,333 & $\$ 0.28$ \\
\hline 7 & $4,900,000$ & 544,444 & 77 & 381,111 & 108,889 & $\$ 0.24$ \\
\hline 8 & $5,600,000$ & 622,222 & 88 & 435,556 & 124,444 & $\$ 0.21$ \\
\hline 9 & $6,300,000$ & 700,000 & 99 & 490,000 & 140,000 & $\$ 0.19$ \\
\hline 10 & $7,000,000$ & 777,778 & 110 & 544,444 & 155,556 & $\$ 0.17$ \\
\hline
\end{tabular}

lifespan. It is a decision-making tool used when there are different operations with unequal service lives [26]. This analysis can help to select the best operation from various alternative operations with different lifespan and cost. The advantage of implementing the EUAC method to perform cost analysis is considering the inflation rate during the operation lifespan. The EUAC concept which determines the annual cost of performing a pavement maintenance treatment is presented in (1).

$$
\mathrm{EUAC}=\frac{P\left(i *(i+1)^{n}\right)}{\left((i+1)^{n}-1\right)},
$$

where $P$ is maintenance treatment cost, $i$ is the inflation rate, and $n$ is life extension of maintenance treatment.

As shown in the above equation, maintenance treatment cost, the life extension of treatment, and the inflation rate are the variables needed to compute the EUAC of a maintenance treatment. The life extension of different maintenance treatments is presented in Table 1. According to the literature reviewed, the inflation rate was between $3.5 \%$ and $4.5 \%$; therefore, in this study, $4 \%$ was adopted. Moreover, Table 2 represents the average price of different maintenance treatments.

According to Table 1 and (1), the EUAC analysis was conducted, and the results are presented in Table 2. As shown, the annual cost of different maintenance treatments based on the existing pavement condition is determined. The most cost-effective maintenance treatment can be selected. The cost-effective maintenance treatment for an existing pavement in different conditions is selected and described below.

It should be noted that in addition to cost consideration, other factors such as aesthetics must be considered. If the client is a member of the Home Owners Association (HOAs), it would be prudent to show pictures and get the HOA to agree to the selected treatment. If the most economical treatment is not esthetically acceptable, the next treatment should be selected and the cost explained to the client.

Pavements in good condition (cracks $<5 \%$ ). According to Table 2, crack sealing has the lowest annual cost among the
TABLE 5: The total annual cost of slurry and chip seal in different pavement conditions.

\begin{tabular}{|c|c|c|c|c|}
\hline \multirow[t]{2}{*}{ Number of clients } & \multicolumn{2}{|c|}{$\begin{array}{c}\text { Chip seal } \\
\text { Total contracted } \\
\text { and admin } \\
\text { expenses } \$ / S Y / y r\end{array}$} & \multicolumn{2}{|c|}{$\begin{array}{c}\text { Slurry seal } \\
\text { Total contracted } \\
\text { and admin } \\
\text { expenses } \$ / S Y / y r\end{array}$} \\
\hline & Good & Fair & Good & Fair \\
\hline 1 & $\$ 3.19$ & $\$ 6.66$ & $\$ 3.00$ & $\$ 5.61$ \\
\hline 2 & $\$ 2.35$ & $\$ 5.82$ & $\$ 2.16$ & $\$ 4.77$ \\
\hline 3 & $\$ 2.07$ & $\$ 5.54$ & $\$ 1.88$ & $\$ 4.49$ \\
\hline 4 & $\$ 1.93$ & $\$ 5.40$ & $\$ 1.74$ & $\$ 4.35$ \\
\hline 5 & $\$ 1.85$ & $\$ 5.31$ & $\$ 1.66$ & $\$ 4.27$ \\
\hline 6 & $\$ 1.79$ & $\$ 5.26$ & $\$ 1.60$ & $\$ 4.21$ \\
\hline 7 & $\$ 1.75$ & $\$ 5.22$ & $\$ 1.56$ & $\$ 4.17$ \\
\hline 8 & $\$ 1.72$ & $\$ 5.19$ & $\$ 1.53$ & $\$ 4.14$ \\
\hline 9 & $\$ 1.70$ & $\$ 5.16$ & $\$ 1.51$ & $\$ 4.12$ \\
\hline 10 & $\$ 1.68$ & $\$ 5.15$ & $\$ 1.49$ & $\$ 4.10$ \\
\hline
\end{tabular}

different maintenance treatments, and its life extension is 2.4 years. The second priority treatment method is chip seals method which can increase pavement life extension up to 3.8 years.

Pavements in fair condition $(5 \%<$ cracks $<20 \%)$. Crack sealing and chip seals have a reasonable EUAC price. While these two treatment methods have the lowest price, they are not commonly implemented in Florida, and slurry seals is the method used in Florida.

Pavement in poor condition (cracks $>20 \%$ ). The deterioration is as much as that a maintenance treatment may not improve the pavement condition. This amount of deterioration makes the pavement rehabilitation necessary. However, chip seals can be used in improving pavement in poor condition, in low traffic. It should be noted, as seen in Table 2, the life extension will be much lower when such treatments are applied to pavements in poor condition.

3.3. Administrative Expenses. In this case study, the PMAR will run its operations out of an office, a yard or a warehouse facility. It will hire office staff and technicians to run the operation. The cost of rent, salaries, insurance, utilities, and 
TABLE 6: Annual profit/loss per SY using chip seal treatment.

\begin{tabular}{|c|c|c|c|c|c|c|c|}
\hline \multirow{3}{*}{$\begin{array}{l}\text { Number of } \\
\text { clients }\end{array}$} & \multicolumn{7}{|c|}{ Chip seal } \\
\hline & \multicolumn{2}{|c|}{ Cost of service $(\$ / y r)$} & \multirow{2}{*}{ Total (\$) } & \multirow{2}{*}{$\begin{array}{c}\text { Annual cost per } 700 \mathrm{~K} \mathrm{SF} \\
\text { property }(\$)\end{array}$} & \multirow{2}{*}{$\begin{array}{c}\text { Annual cost per } \\
\text { SY }(\$)\end{array}$} & \multirow{2}{*}{$\begin{array}{c}\text { Profit/loss-charging } \\
\$ 3 / \mathrm{SY} / \mathrm{yr}\end{array}$} & \multirow{2}{*}{$\begin{array}{c}\text { Profit/loss- } \\
\text { charging } \\
\$ 3.5 / \mathrm{SY} / \mathrm{yr}\end{array}$} \\
\hline & Good & Fair & & & & & \\
\hline 1 & $\$ 173,701.11$ & $\$ 155,363.33$ & $\$ 170,550.61$ & $\$ 329,064.44$ & $\$ 4.23$ & $-\$ 95,731.11$ & $-\$ 56,842.22$ \\
\hline 2 & $\$ 255,912.22$ & $\$ 271,516.67$ & $\$ 210,401.23$ & $\$ 527,428.89$ & $\$ 3.39$ & $-\$ 60,762.22$ & $\$ 17,015.56$ \\
\hline 3 & $\$ 338,123.33$ & $\$ 387,670.00$ & $\$ 250,251.84$ & $\$ 725,793.33$ & $\$ 3.11$ & $-\$ 25,793.33$ & $\$ 90,873.33$ \\
\hline 4 & $\$ 420,334.44$ & $\$ 503,823.33$ & $\$ 290,102.45$ & $\$ 924,157.78$ & $\$ 2.97$ & $\$ 9,175.56$ & $\$ 164,731.11$ \\
\hline 5 & $\$ 502,545.56$ & $\$ 619,976.67$ & $\$ 329,953.07$ & $\$ 1,122,522.22$ & $\$ 2.89$ & $\$ 44,144.44$ & $\$ 238,588.89$ \\
\hline 6 & $\$ 584,756.67$ & $\$ 736,130.00$ & $\$ 369,803.68$ & $\$ 1,320,886.67$ & $\$ 2.83$ & $\$ 79,113.33$ & $\$ 312,446.67$ \\
\hline 7 & $\$ 666,967.78$ & $\$ 852,283.33$ & $\$ 409,654.29$ & $\$ 1,519,251.11$ & $\$ 2.79$ & $\$ 114,082.22$ & $\$ 386,304.44$ \\
\hline 8 & $\$ 749,178.89$ & $\$ 968,436.67$ & $\$ 449,504.91$ & $\$ 1,717,615.56$ & $\$ 2.76$ & $\$ 149,051.11$ & $\$ 460,162.22$ \\
\hline 9 & $\$ 831,390.00$ & $\$ 1,084,590.00$ & $\$ 489,355.52$ & $\$ 1,915,980.00$ & $\$ 2.74$ & $\$ 184,020.00$ & $\$ 534,020.00$ \\
\hline 10 & $\$ 913,601.11$ & $\$ 1,200,743.33$ & $\$ 529,206.13$ & $\$ 2,114,344.44$ & $\$ 2.72$ & $\$ 218,988.89$ & $\$ 607,877.78$ \\
\hline
\end{tabular}

TABLE 7: Annual profit/loss per SY using slurry seal treatment.

\begin{tabular}{|c|c|c|c|c|c|c|c|}
\hline \multirow{3}{*}{$\begin{array}{l}\text { Number of } \\
\text { clients }\end{array}$} & \multicolumn{7}{|c|}{ Slurry seal } \\
\hline & \multicolumn{2}{|c|}{ Cost of service $(\$ / y r)$} & \multirow{2}{*}{ Total $(\$)$} & \multirow{2}{*}{$\begin{array}{l}\text { Annual cost per } \\
700 \mathrm{~K} \text { SF property } \\
(\$)\end{array}$} & \multirow{2}{*}{$\begin{array}{c}\text { Annual cost per SY } \\
(\$)\end{array}$} & \multirow{2}{*}{$\begin{array}{c}\text { Profit/loss- } \\
\text { charging } \\
\$ 3 / S Y / y r\end{array}$} & \multirow{2}{*}{$\begin{array}{c}\text { Profit/loss- } \\
\text { charging } \\
\$ 3.5 / \mathrm{SY} / \mathrm{yr}\end{array}$} \\
\hline & Good & Fair & & & & & \\
\hline 1 & $\$ 163,302.22$ & $\$ 130,980.00$ & $\$ 294,282.22$ & $\$ 294,282.22$ & $\$ 3.78$ & $-\$ 60,948.89$ & $-\$ 22,060.00$ \\
\hline 2 & $\$ 235,114.44$ & $\$ 222,750.00$ & $\$ 457,864.44$ & $\$ 228,932.22$ & $\$ 2.94$ & $\$ 8,802.22$ & $\$ 86,580.00$ \\
\hline 3 & $\$ 306,926.67$ & $\$ 314,520.00$ & $\$ 621,446.67$ & $\$ 207,148.89$ & $\$ 2.66$ & $\$ 78,553.33$ & $\$ 195,220.00$ \\
\hline 4 & $\$ 378,738.89$ & $\$ 406,290.00$ & $\$ 785,028.89$ & $\$ 196,257.22$ & $\$ 2.52$ & $\$ 148,304.44$ & $\$ 303,860.00$ \\
\hline 5 & $\$ 450,551.11$ & $\$ 498,060.00$ & $\$ 948,611.11$ & $\$ 189,722.22$ & $\$ 2.44$ & $\$ 218,055.56$ & $\$ 412,500.00$ \\
\hline 6 & $\$ 522,363.33$ & $\$ 589,830.00$ & $\$ 1,112,193.33$ & $\$ 185,365.56$ & $\$ 2.38$ & $\$ 287,806.67$ & $\$ 521,140.00$ \\
\hline 7 & $\$ 594,175.56$ & $\$ 681,600.00$ & $\$ 1,275,775.56$ & $\$ 182,253.65$ & $\$ 2.34$ & $\$ 357,557.78$ & $\$ 629,780.00$ \\
\hline 8 & $\$ 665,987.78$ & $\$ 773,370.00$ & $\$ 1,439,357.78$ & $\$ 179,919.72$ & $\$ 2.31$ & $\$ 427,308.89$ & $\$ 738,420.00$ \\
\hline 9 & $\$ 737,800.00$ & $\$ 865,140.00$ & $\$ 1,602,940.00$ & $\$ 178,104.44$ & $\$ 2.29$ & $\$ 497,060.00$ & $\$ 847,060.00$ \\
\hline 10 & $\$ 809,612.22$ & $\$ 956,910.00$ & $\$ 1,766,522.22$ & $\$ 176,652.22$ & $\$ 2.27$ & $\$ 566,811.11$ & $\$ 955,700.00$ \\
\hline
\end{tabular}

vehicles should be added up to determine the annual value. In this case, the total annual administrative expenses are $\$ 130,700$. This cost is converted to cost per SY/year.

3.4. Total Cost. The annual administrative expenses, as calculated above ( $\$ 130,700$ per year), are converted to cost in $\$ /$ SY per year. This is done by dividing the annual admin cost by the total square yards the PMAR is servicing. Obviously, the more square yards serviced, the less administrative expenses charged per unit area. The administrative cost is then added to the EUAC/SY. The admin expense per SY determined by assuming ten clients each has 700,000 SF paved area. This is about the average size residential community in Florida. Table 3 presents the total construction cost for chip seals and slurry seals treatment.

Table 4 shows the annual admin expense per SY. It should be noted that it was assumed that $70 \%$ of the treatment area of each client is in good condition and 30\% in fair condition. The total cost of treatment is determined in Table 5. The total cost is calculated by adding the admin cost in Table 4 and the treatment cost in Table 3 in respective pavement conditions.

3.5. Profit/Loss Analysis. The final step in PMAR is computing the profit/loss which is presented in Tables 6 and 7 for chip seal and slurry seal, respectively. The cost of service is calculated by multiplying the cost of treatment by the area of the treatment at each condition. The total cost is the sum up of service cost in different pavement conditions. The annual cost per $700 \mathrm{~K} \mathrm{SF}$ property is the total cost per client. The annual cost per SY is the total construction cost per SY. Two options were considered to evaluate the profit/loss amount. It was assumed that the annual premium charged by the PMAR being $\$ 3$ or $\$ 3.5$ per SY. Then the profit/loss was evaluated as the differences of charge and annual cost in the area of treatment.

As shown in Tables 6 and 7, by increasing the number of clients or serviced area, the amount of profit is increased. It is shown that slurry seals price is less than the chip seal, causing more profit in using slurry seal in comparison with chip seal. The profit/loss is a function of SY contracted pavement, from Tables 6 and 7, which is depicted in Figure 3.

The minimum amount of maintained pavement area needed for the PMAR to break even is shown in Figure 3. If the PMAR charges the client $\$ 3.0 / \mathrm{SY} / \mathrm{yr}$ or $\$ 3.5 / \mathrm{SY} / \mathrm{yr}$, then 41 lane miles $(290,703 \mathrm{SY})$ or 20 lane miles $(137,637 \mathrm{SY})$ of pavement is required to break even with chip seal, respectively. For the slurry seal, 21 lane miles $(145,740 \mathrm{SY})$ or 14 lane miles $(93,571 \mathrm{SY})$ of serviced area is needed to break even with $\$ 3.0 / \mathrm{SY} / \mathrm{yr}$ or $\$ 3.5 / \mathrm{SY} / \mathrm{yr}$ charge, respectively. This analysis demonstrated the long-term financial risk associated with the implementation of a pavement treatment. 


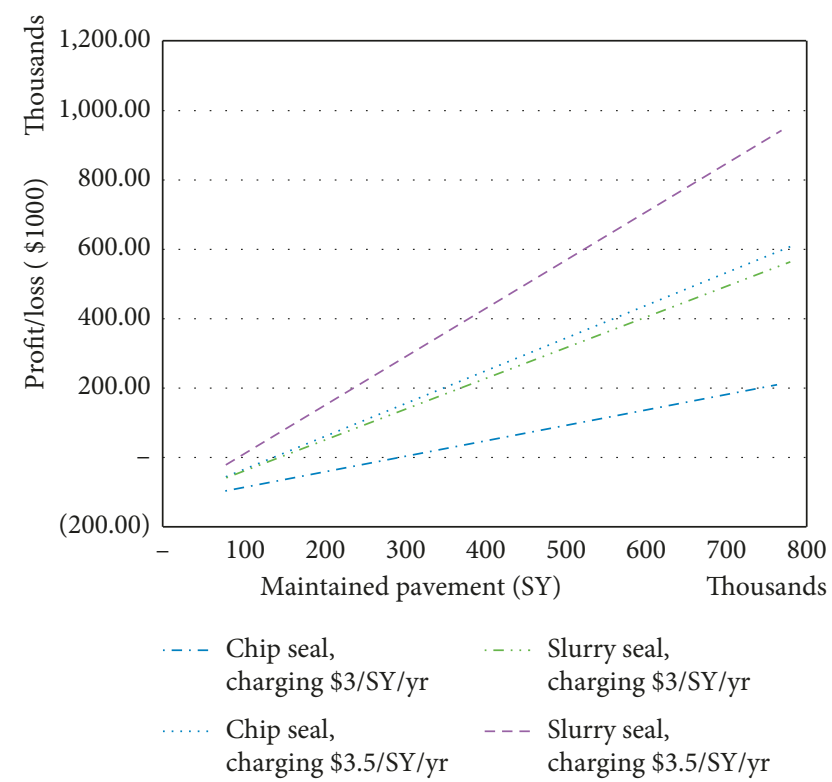

Figure 3: Profit/loss in implementing chip seals and slurry seals.

\section{Summary}

The concept of the Pavement Manager at Risk (PMAR) is advocated. PMAR is a contractual arrangement where Pavement Manager enters into a contract with a road owner to maintain its roads for a period of time. This agreement is long term in nature, preferably more than 5 years. The agreement is performance-based. PMAR studies the roads, determines the best long-term maintenance strategy, implements a pavement management program, and guarantees to the owner a certain level of service. The PMAR does not bid materials or labor. It bids a minimum level of service. In return for the service, the PMAR charges a set per SY (square yard) year premiums. The pavement manager will take the risk and reward for pavement performance during its service life.

The advantage of this arrangement is that a professional who is knowledgeable about pavement management is in charge of making rehabilitation decision. Since the PMAR is financially impacted by the ultimate pavement performance, its attention will be focused on cost-effective products and best maintenance strategies. This arrangement should accelerate the evolution of pavement management and promote effective products. Another advantage is it provides clients with a fixed annual cost for maintaining the roads. This is very desirable as swinging budgets can be difficult to manage for clients like the Home Owners Associations.

In the PMAR arrangement, the cost of maintenance, admin expenses, occasional patching expenses, and mobilization and striping expenses are included. To illustrate the PMAR procedure, a hypothetical case study was presented. Some elements need to be further developed to make the concept work. These include cash flow issues, hand over requirements, and warranty requirements.

\section{Conflicts of Interest}

The authors declare that there are no conflicts of interest regarding the publication of this paper.

\section{References}

[1] R. Hicks, J. Moulthrop, and J. Daleiden, "Selecting a preventive maintenance treatment for flexible pavements," Transportation Research Record: Journal of the Transportation Research Board, vol. 1680, pp. 1-12, 1999.

[2] P. Mandiartha, C. F. Duffield, R. G. Thompson, and M. R. Wigan, "Measuring pavement maintenance effectiveness using Markov chains analysis," Structure and Infrastructure Engineering, vol. 13, no. 7, pp. 844-854, 2016.

[3] Q. J. Li, Y. Zhan, G. Yang, K. C. P. Wang, and C. Wang, "Panel data analysis of surface skid resistance for various pavement preventive maintenance treatments using long term pavement performance (LTPP) data," Canadian Journal of Civil Engineering, vol. 44, no. 5, pp. 358-366, 2017.

[4] M. Baqersad, A. Hamedi, M. Mohammadafzali, and H. Ali, "Asphalt mixture segregation detection: digital image processing approach," Advances in Materials Science and Engineering, vol. 2017, Article ID 9493408, 6 pages.

[5] A. Massahi, H. Ali, F. Koohifar, M. Baqersad, and M. Mohammadafzali, "Investigation of pavement raveling performance using smartphone," International Journal of Pavement Research and Technology, 2017, In press.

[6] M. Baqersad, M. Mohammadafzali, B. Choubane, C. Holzschuher, A. Hamedi, and H. Ali, "Precision assessment of the Florida texture meter in hot mix asphalt," Journal of Transportation Engineering, Part B: Pavements, vol. 144, no. 2, p. 04018003, 2018.

[7] A. Massahi, H. Ali, F. Koohifar, M. Baqersad, and M. Mohammadafzali, "Implementing a smartphone application for assessing the raveling performance of asphalt pavements," International Journal of Advances in Scientific Research and Engineering, vol. 4, no. 3, pp. 68-76, 2018.

[8] M. Y. Shahin, Pavement Management for Airports, Roads, and Parking Lots, Vol. 501, Springer, New York, NY, USA, 2005.

[9] J. Bausano, K. Chatti, and R. Williams, "Determining life expectancy of preventive maintenance fixes for asphalt-surfaced pavements," Transportation Research Record: Journal of the Transportation Research Board, vol. 1866, pp. 1-8, 2004.

[10] J. Yang, "Estimation of pavement lifespan using stochastic duration models," in Proceedings of the Transportation Research Board 86th Annual Meeting, Washington, DC, USA, January 2007.

[11] F. Haddadi, M. Ameri, M. H. Mirabimoghadam, and H. R. A. Hosseini, "Validation of a simplified method in viscoelastic continuum damage (VECD) model developed for flexural mode of loading," Construction and Building Materials, vol. 95, pp. 892-897, 2015.

[12] M. Mohammadafzali, H. Ali, J. A. Musselman, G. A. Sholar, and A. Massahi, "Evaluation of cracking resistance and durability of $100 \%$ reclaimed asphalt pavement mixtures," Advances in Civil Engineering, vol. 2017, Article ID 7240462, 7 pages, 2017.

[13] J. Sousa and G. Way, Considerations for Estimating Pavement Treatment Lives and Life Extension on Flexible Pavements, Draft Report Submitted to the CP2 Center, 2007.

[14] R. Dekker, "Applications of maintenance optimization models: a review and analysis," Reliability Engineering and System Safety, vol. 51, no. 3, pp. 229-240, 1996. 
[15] R. Haas and W. R. Hudson, Pavement Management Systems, McGraw-Hill, New York, NY, USA, 1978.

[16] N. Bandara and M. Gunaratne, "Current and future pavement maintenance prioritization based on rapid visual condition evaluation," Journal of Transportation Engineering, vol. 127, no. 2, pp. 116-123, 2001.

[17] H. Ali and M. Mohammadafzali, Asphalt Surface Treatment Practice in Southeastern United States, Florida International University, Miami, FL, USA, 2014.

[18] D. G. Peshkin, T. E. Hoerner, and K. A. Zimmerman, Optimal Timing of Pavement Preventive Maintenance Treatment Applications, Transportation Research Board, Vol. 523, Transportation Research Board, Washington, DC, USA, 2004.

[19] K. T. Hall, C. E. Correa, S. H. Carpenter, and R. P. Elliot, Rehabilitation Strategies for Highway Pavements: National Cooperative Highway Research Program, Web Document 35, NCHRP, Washington, DC, USA, 2001.

[20] R. Smith, T. Freeman, and O. Pendleton, Pavement Maintenance Effectiveness, Strategic Highway Research Program, National Research Council, Washington, DC, USA, 1993.

[21] A. H. Massahi, M. Hadi, M. A. Cutillo, and Y. Xiao, "Estimating the capacity impacts of urban street incidents," in Proceedings of the Transportation Research Board 96th Annual Meeting, Transportation Research Board, Washington, DC, USA, January 2017.

[22] A. A. Kebede, Asphalt Pavement Preservation using Rejuvenating Fog Seals, Purdue University, Lafayette, IN, USA, 2016.

[23] H. J. Son, Y. J. Kim, J. E. Baek, J. K. Lim, and B. I. Kim, "Field performance evaluation of micro-surfacing method and polymer slurry seal method used in national highway," Journal of the Korean Society of Road Engineers, vol. 17, no. 1, pp. 17-24, 2015.

[24] J. Yu, X. Zhang, and C. Xiong, "A methodology for evaluating micro-surfacing treatment on asphalt pavement based on grey system models and grey rational degree theory," Construction and Building Materials, vol. 150, pp. 214-226, 2017.

[25] X. Zhang, X. Gu, Z. Huang, B. Yu, and F. Ni, "Laboratory investigation on performance of basalt fiber reinforced asphalt chip seal," in Proceedings of the Transportation Research Board 95th Annual Meeting, Washington, DC, USA, January 2016.

[26] K. A. Abaza, "Optimum flexible pavement life-cycle analysis model," Journal of Transportation Engineering, vol. 128, no. 6, pp. 542-549, 2002. 


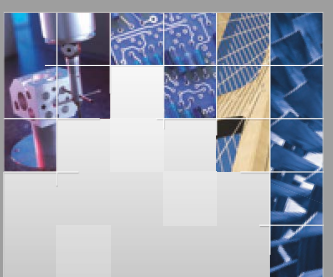

\section{Enfincering}
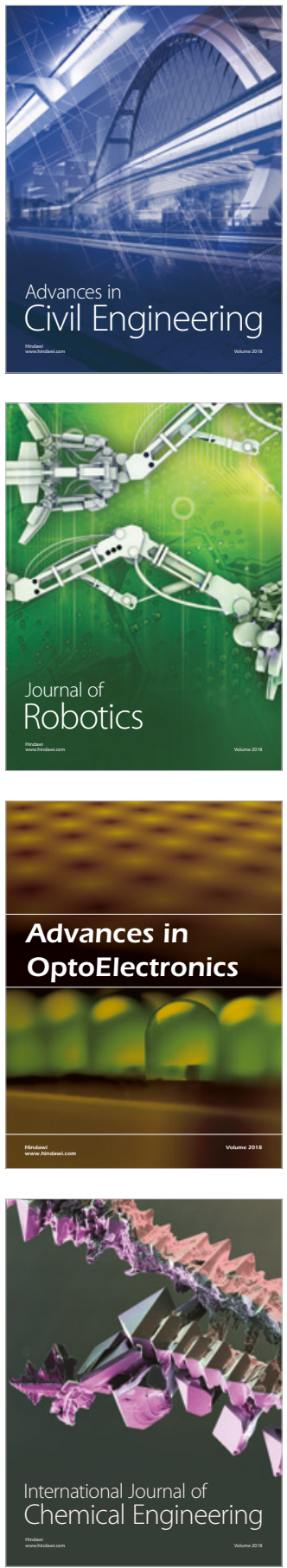

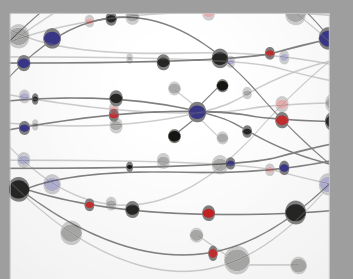

\section{Rotating \\ Machinery}

The Scientific World Journal

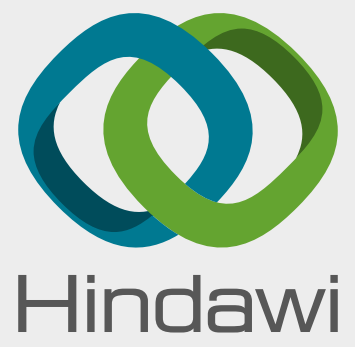

Submit your manuscripts at

www.hindawi.com
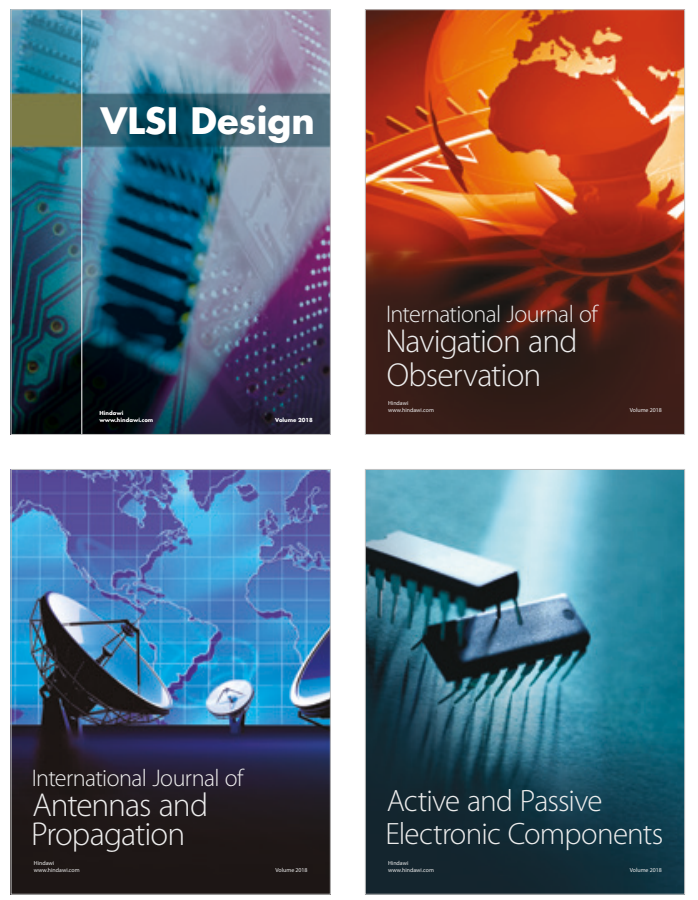
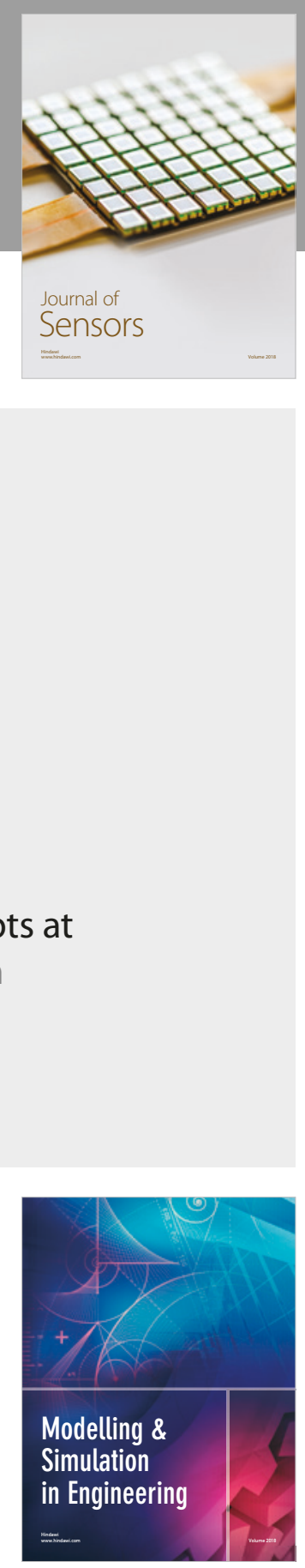

\section{Advances \\ Multimedia}
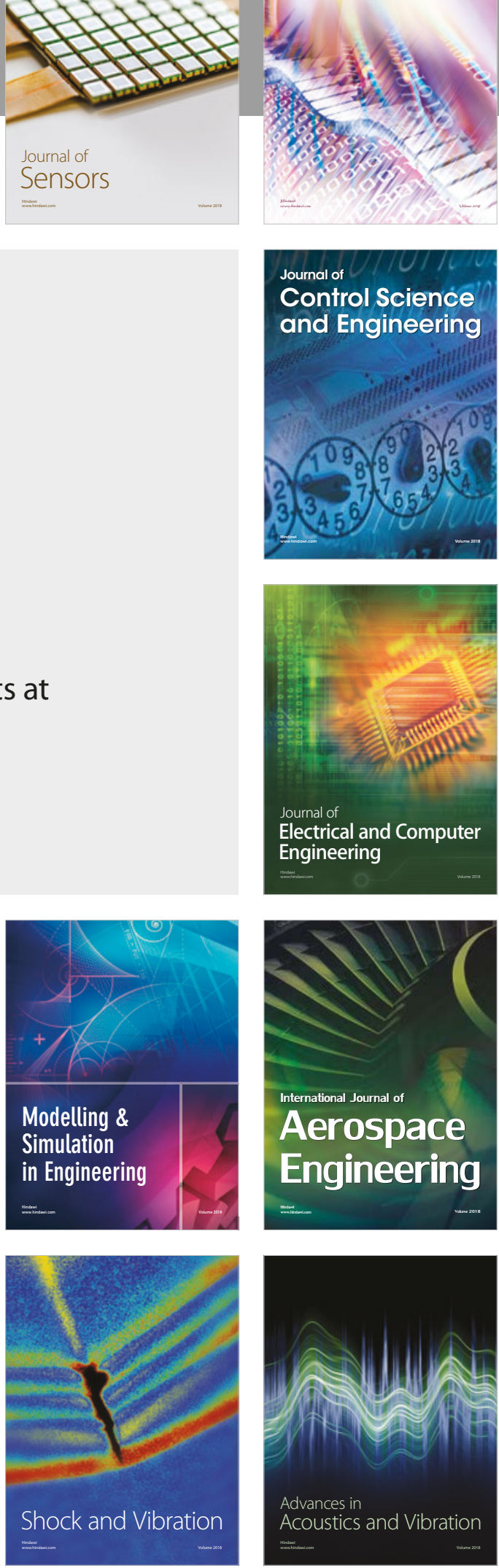